\title{
LRP6 wt Allele
}

National Cancer Institute

\section{Source}

National Cancer Institute. LRP6 wt Allele. NCI Thesaurus. Code C95413.

Human LRP6 wild-type allele is located in the vicinity of 12p13.2 and is approximately 151 $\mathrm{kb}$ in length. This allele, which encodes low-density lipoprotein receptor-related protein 6 , is involved in the mediation of ligand endocytosis and cell communication. Mutation of the gene is associated with autosomal dominant coronary artery disease type 2 . 